\title{
Rational use of cetuximab in the treatment of advanced non-small cell lung cancer
}

This article was published in the following Dove Press journal:

OncoTargets and Therapy

26 August 2009

Number of times this article has been viewed

\author{
Charu Aggarwal \\ Hossein Borghaei \\ Department of Medical Oncology, \\ Fox Chase Cancer Center, \\ Philadelphia, PA, USA
}

Correspondence: Hossein Borghaei Department of Medical Oncology, Fox Chase Cancer Center,

333 Cottman Avenue,

Philadelphia, PA I91।I, USA

Tel + | 2/5-2|4-4297

Email hossein.borghaei@fccc.edu
Abstract: Lung cancer is the leading cause of mortality in the United States. Non-small cell lung cancer (NSCLC) accounts for approximately 85\% of all lung cancers. Most NSCLC patients present with loco-regionally advanced or metastatic disease where response rates are low and median overall survival approximates 8 to 10 months. Chemotherapy is the mainstay of treatment for NSCLC patients with metastatic disease. Epidermal growth factor receptor (EGFR) and family of receptors play a critical role in lung cancer tumorigenesis. Cetuximab, a monoclonal antibody that binds the EGFR, has demonstrated preclinical and clinical activity against NSCLC. This review focuses on the use of cetuximab in NSCLC.

Keywords: cetuximab, lung cancer, monoclonal antibody

\section{Introduction}

Lung cancer is the leading cause of cancer related mortality in the United States. ${ }^{1,2}$ Non-small cell lung cancer (NSCLC) accounts for approximately $85 \%$ of all lung cancer cases and encompasses different histologies including squamous cell carcinoma, large cell carcinoma and adenocarcinoma with or without bronchioalveolar features.

NSCLC is staged according to the TNM (tumor, node, and metastasis) system. ${ }^{3,4}$ Early stage lung cancer represents a minority of cases and is often curable with surgery with or without adjuvant chemotherapy. Adjuvant chemotherapy consisting of a cisplatin-based doublet is associated with improved survival in patients with resected stage II-IIIA lung cancer..$^{5-9}$ Some patients with stage IB lung cancer may also derive a benefit from chemotherapy..$^{10}$ The optimal management of unresectable stage IIIA NSCLC is controversial and depends on the nodal status and tumor size and location. ${ }^{11}$

A sizeable majority of patients with NSCLC present with distant metastases where chemotherapy is the mainstay of treatment. In the 1980s, doxorubicin- and cyclophosphamide-containing regimens were used without substantially improving survival. ${ }^{12-14}$ Subsequently single-agent chemotherapy with paclitaxel, gemcitabine, and vinorelbine was compared to best supportive care, suggesting a favorable survival trend for chemotherapy with these agents. ${ }^{15-17}$ Based on these encouraging results, trials of combination chemotherapy with cisplatin and the previously used single agents were conducted and showed a further improvement in overall and disease-free survival. ${ }^{18,19}$ These trials established platinum doublet as the cornerstone of chemotherapy for advanced NSCLC. Equivalence of different platinum doublet combinations was demonstrated in randomized phase III studies. ${ }^{20-22}$ In a recent landmark trial, addition of bevacizumab, an antibody against the vascular endothelial 
growth factor, to carboplatin and paclitaxel was associated with improved overall and progression-free survival (PFS) in patients with non-squamous histologies. ${ }^{23}$ This was the first trial to show an improvement in survival with the use of targeted agents in addition to standard chemotherapy in patients with NSCLC. In another trial, addition of bevacizumab to cisplatin and gemcitabine was associated with significant improvement in PFS and response rate. ${ }^{24}$

A more recent trial compared cisplatin and pemetrexed to cisplatin and gemcitabine, with similar overall survival and somewhat better tolerability for the pemetrexed-containing arm. However, in a prespecified subset analysis, the cisplatin and pemetrexed arm demonstrated statistically significant improvement in survival for the adenocarcinoma and large cell carcinoma histologies. ${ }^{25}$ Conversely, the cisplatin and gemcitabine arm proved to be superior for the squamous cell cancers of the lung.

Currently, palliative chemotherapy is the standard of care for patients with metastatic NSCLC. First-line treatment involves administration of 4 to 6 cycles of platinum-containing doublet chemotherapy ${ }^{26,27}$ with or without bevacizumab. ${ }^{23,24}$ The addition of bevacizumab and pemetrexed in specific subsets of NSCLC have resulted in modest improvements in survival, however these have only been seen in select patient populations. Newer therapies are therefore desperately needed to improve outcomes in the greater majority of patients with NSCLC.

\section{Epidermal growth factor receptor}

The epidermal growth factor receptor (EGFR) is one of a family of receptors that has growth promoting effects in NSCLC. EGFR is overexpressed in about $40 \%$ to $80 \%$ of NSCLC. ${ }^{28}$ Downstream signaling by the activated EGFR can be abrogated by small molecule inhibitors, such as erlotinib and gefitinib or by monoclonal antibodies directed towards the extracellular domain of EGFR, such as cetuximab.

The EGFR (ErbB1) is a transmembrane receptor of the tyrosine kinase (TK) family of receptors. It is a $170 \mathrm{kDa}$ protein and has 3 closely related members, HER2/Neu (ErbB2), HER3 (ErbB3), and HER4 (ErbB4). All members, except for HER2/Neu, have an extracellular ligand binding domain. Additionally all members, except HER3, are equipped with an intracellular domain with TK activity. Ligand binding results in receptor homodimerization or heterodimerization and consequent phosphorylation of the TK domain. EGF and transforming growth factor (TGF) alpha appear to be key ligands, but others, like epiregulin, betacellulin, epigen, and amphiregulin, have been shown to be relevant predictors of response and resistance. ${ }^{29,30}$ A series of downstream signals lead to tumor proliferation, angiogenesis, and inhibition of apoptosis by the Ras-Raf-Mitogen activated protein kinase (MAPK) and phosphatidylinositol-3-kinase (PI3)-Akt pathways. ${ }^{31,32}$ Interaction between EGFR expression and STAT 3 (signal transducers and activators of transcription 3 ) has also been shown to be important in gene transcription. ${ }^{33-35}$

Small-molecule EGFR TK inhibitors (TKIs) are competetive inhibitors and bind reversibly to the intracellular catalytic domain of EGFR tyrosine kinase and, thus, inhibit EGFR autophosphorylation and downstream signaling. Anti-EGFR monoclonal antibodies, on the other hand, recognize EGFR exclusively and are therefore highly selective for this receptor. In addition, various small-molecule EGFR TKIs can block different growth factor receptor TKs, including other members of the EGFR family, while antibodies are fairly specific. Erlotinib is approved for second- or third-line treatment in chemotherapy-resistant advanced NSCLC based on superior overall survival results from a phase III randomized study. ${ }^{36}$ Females, non-smokers, Asian patients, and patients with adenocarcinoma and EGFR mutations derive the maximum benefit when treated with small molecule TKIs. ${ }^{37}$ In combination with chemotherapy, erlotinib did not confer any additional benefit over chemotherapy alone in two separate phase III trials. ${ }^{38,39}$ Therefore, at this point erlotinib is used in patients with evidence of recurrent disease. A study to evaluate the role of this agent in the maintenance setting is ongoing. Also, the potential use of this agent in the front-line setting in patients with activating EGFR mutations is under investigation. This review will focus on pharmacology, safety, efficacy, and future directions of the use of cetuximab in NSCLC.

\section{Pharmacology of cetuximab}

Murine antibody to EGFR, mAb225, was initially developed from a panel of anti-EGFR antibodies based upon receptor affinity and efficacy. ${ }^{40}$ All patients treated with this antibody in a phase I study developed human antimurine antibodies. Therefore a chimeric human-mouse version of mAb225 (C225, cetuximab) was produced. Cloned heavy and light chains of mAb225 were adapted for expression with a constant region of the human kappa light chain and human gamma 1 heavy chain. This antibody, cetuximab, binds to EGFR with higher affinity than its murine counterpart. ${ }^{41-44}$

Initial phase I trials established 400 to $500 \mathrm{mg} / \mathrm{m}^{2}$ intravenously (iv) as loading dose to be followed by $250 \mathrm{mg} / \mathrm{m}^{2}$ iv weekly based on adverse effect profile and pharmacokinetic parameters. ${ }^{42,45,46}$ 
Epithelial cancers are often associated with activation of growth factor receptors of the EGFR family. Anti-EGFR antibodies recognize EGFR exclusively and are therefore highly selective for this receptor. The EGFR has an extracellular and intracellular domain. The extracellular domain has 4 subunits, which exist in a compact, tethered auto-inhibited condition in the absence of a ligand. ${ }^{47}$ Cetuximab prevents ligand binding to EGFR, inhibits receptor dimerization, and therefore blocks downstream signaling. Cetuximab binds to domain III of the receptor and sterically blocks access to the key ligand binding region of the receptor. There is also evidence that, in the presence of cetuximab, the EGFR extracellular component cannot adopt the extended dimerization configuration preventing its activation. ${ }^{47}$ It binds with higher affinity than its endogenous ligands and promotes receptor internalization and degradation..$^{48}$ By promoting receptor removal from the cell surface, cetuximab also reduces the active pool of protein available to signal. ${ }^{49}$

EGFR pathway is important in proliferation, metastasis, cancer cell invasion, and angiogenesis. ${ }^{50}$ Blockade of EGFR pathway by cetuximab leads to inhibition of cancer cell proliferation (blockade of cell cycle progression and G1 arrest through an increase in p27kip 1 inhibitor of cyclin-dependent kinases), ${ }^{51-53}$ inhibition of tumor-induced angiogenesis by blockade of production of angiogenic factors (transforming growth factor alpha, VEGF, IL8, basic FGF), inhibition of invasion and metastasis, and potentiation of antitumor activity of cytotoxic drugs and radiation therapy. ${ }^{44,54}$ There is also evidence of IgG1-mediated antibody directed cell mediated cytotxicity (ADCC)..$^{55}$

In preclinical animal models, cetuximab and other epidermal growth factor receptor antagonists have been shown to be synergistic with cisplatin ${ }^{56,57}$ and paclitaxel..$^{58,59}$ In a preclinical study, the efficacy of combination of cetuximab and paclitaxel was evaluated for treating human transitional cell carcinoma (TCC) of the urinary bladder of nude mice. ${ }^{59}$ Paclitaxel demonstrated significant antitumor activity and the extent of paclitaxel-induced apoptosis was enhanced in the presence of reduced Raf- 1 activity. ${ }^{60}$ Cetuximab downregulates Raf-1 activity, and presumably by this mechanism cetuximab enhances the antiproliferative and apoptotic effects of paclitaxel in a dose-dependent manner in vitro. A second hypothesis for this synergy is that treatment with paclitaxel may upregulate EGFR receptors in tumor cells, making cells more susceptible to anti-EGFR therapies.

Resistance eventually emerges in most tumors initially susceptible to anti-EGFR approaches. Various mechanisms of resistance have been documented in preclinical and clinical models. Active EGFR signaling may lead to resistance by upregulation of ATP-binding cassette (ABC) proteins. $\mathrm{ABC}$ proteins confer resistance by actively pumping drugs out of the cancer cell. In breast adenocarcinoma cell lines, activation of the EGFR pathway is linked to activation of the multidrug resistance transporter family. ${ }^{61}$ EGFR resistance may also be due to mutations in the receptor protein itself. The T790M mutation substitutes methionine for a threonine residue, leading to resistance by reducing affinity to smallmolecule TKIs and increasing competitive ATP binding. ${ }^{62}$ This mutation is seen in about $50 \%$ of patients demonstrating acquired resistance to TKIs. Heterodimerization with other HER partners may represent an alternative mechanism of resistance. Cancer cells expressing EGFR and ErbB2 are nonresponsive to inhibitors targeting one of these two proteins. ${ }^{63}$ Similarly, overexpression of ErbB3 also confers resistance to EGFR inhibitors. ${ }^{64}$ Expression of hepatocyte growth factor and c-Met dependent signaling is also an alternative pathway for signaling conferring resistance (seen in approximately $20 \%$ of patients with acquired resistance to TKIs). ${ }^{65}$ Finally, interactions between EGFR and the insulin growth factor receptor (IGF-1R) can provide resistance to agents targeting EGFR. ${ }^{66}$

Although the above mechanisms are mainly responsible for resistance to TKIs, downstream activating mutations of the core effector pathway play a central role in mediating resistance to agents targeted both intracellularly and extracellularly. The most validated downstream resistance mechanism is the KRAS pathway. Mutant KRAS exists in the activated state and constitutively activates downstream signals of cell proliferation, motility and metastasis, and survival. Mutant KRAS (found in approximately $15 \%$ to $30 \%$ of patients with NSCLC) is associated with worse survival in response to EGFR antibodies in colorectal cancers. ${ }^{67-69}$ In NSCLC, a retrospective analysis of tumor samples from erlotinib or gefitinib sensitive patients revealed that KRAS mutation was associated with resistance to either therapy. ${ }^{70}$ Clinical data from the FLEX study ${ }^{71}$ do not support the hypothesis that KRAS mutation status is predictive for cetuximab efficacy when combined with first-line chemotherapy in advanced NSCLC, whereas early acne-like rash of any grade appears to be associated with better outcome in patients treated with cetuximab. ${ }^{72}$

EGFR expression by immunohistochemistry and amplification by fluorescence in situ hybridization (FISH) have been evaluated as potential markers for response to EGFR targeted agents. ${ }^{73,74}$ These have not been associated with differential outcomes in response to EGFR TKIs. 
However, in a recent study, increase in EGFR gene copy number by FISH ( 4 or more gene copies per cell in $\geq 40 \%$ of the cells or gene amplification) was shown to predict for survival in advanced-stage NSCLC receiving sequential or concurrent chemotherapy (paclitaxel plus carboplatin) with cetuximab. Larger, prospective confirmatory studies are required for confirmation of this observation. ${ }^{75}$

\section{Clinical efficacy in first-line setting}

NSCLCs often overexpress EGFR, making cetuximab an attractive targeted agent for use in these patients. ${ }^{76}$ It has been used in several trials in the first-line setting in stage IIIb/IV NSCLC (Table 1).

In a multicenter phase I/II study, Thienelt et al used cetuximab in the first-line setting in combination with carboplatin at an area under the curve (AUC) of 6 and paclitaxel $\left(225 \mathrm{mg} / \mathrm{m}^{2}\right)$ in patients with advanced stage NSCLC. ${ }^{77}$ Cetuximab was administered iv at $400 \mathrm{mg} / \mathrm{m}^{2}$, 1 week before paclitaxel and carboplatin, then weekly at $250 \mathrm{mg} / \mathrm{m}^{2}$ (standard dosing). Patients had to have EGFR positive disease by immunohistochemistry (IHC), performance status (PS) of 0 to 2 , and measurable disease. The regimen was continued until disease progression or intolerable toxicity. Patients who did not tolerate chemotherapy because of toxicity could continue on weekly cetuximab monotherapy until disease progression or unacceptable toxicity. Thirty-one patients were treated and an objective response was observed in 8 patients $(26 \%)$. At a median follow-up of 19 months, the median time to progression (TTP) was 5 months, median survival was 11 months, and the 1- and 2-year survival rates

Table I Trials evaluating use of cetuximab in combination with chemotherapy in first-line setting in Stage IIIb/IV NSCLC

\begin{tabular}{|c|c|c|c|c|}
\hline Author & Phase & $\mathbf{n}$ & Chemotherapy ${ }^{\mathbf{a}}$ & Results for cetuximab group \\
\hline Thienelt et $\mathrm{al}^{77}$ & $\mathrm{I} / \mathrm{lla}$ & 31 & $\begin{array}{l}\text { Cb AUC } 6 \\
\text { T } 225 \mathrm{mg} / \mathrm{m}^{2} \\
\text { (every } 3 \mathrm{wk} \text { ) }\end{array}$ & $\begin{array}{l}\text { Median OS II mos } \\
\text { Median TTP } 5 \text { mos }\end{array}$ \\
\hline Robert et $\mathrm{al}^{78}$ & $\mathrm{I} / \mathrm{lla}$ & 35 & $\begin{array}{l}\text { Cb AUC } 5 \\
\text { Gem } 1000 \mathrm{mg} / \mathrm{m}^{2}(\mathrm{dl}, 8) \text { (every } 3 \mathrm{wk} \text { ) }\end{array}$ & $\begin{array}{l}\text { Median OS } 320 \text { days } \\
\text { Median TTP } 165 \text { days }\end{array}$ \\
\hline Butts et al ${ }^{79}$ & ॥ & $|3|$ & $\begin{array}{l}\text { Cb AUC } 5 \text { or CDDP } 75 \mathrm{mg} / \mathrm{m}^{2} \\
\text { Gem } 1000 \mathrm{mg} / \mathrm{m}^{2}(\mathrm{dl}, 8) \\
\text { (every } 3 \mathrm{wk} \text { ) }\end{array}$ & $\begin{array}{l}\text { Median OS } 11.99 \text { mos } \\
\text { Median PFS } 5.09 \text { mos }\end{array}$ \\
\hline Spigel et $\mathrm{a}^{80}$ & II & 27 & $\begin{array}{l}\text { Gem } 1000 \mathrm{mg} / \mathrm{m}^{2} \text { IV } \\
\text { Doc } 30 \mathrm{mg} / \mathrm{m}^{2} \text { IV days I, } 8 \\
\text { (every } 3 \mathrm{wk} \text { ) }\end{array}$ & $\begin{array}{l}\text { Median OS NR } \\
\text { Median PFS NR }\end{array}$ \\
\hline Belani et $\mathrm{al}^{81}$ & ॥ & 80 & $\begin{array}{l}\text { Cb AUC } 6 \\
\text { Docetaxel } 75 \mathrm{mg} / \mathrm{m}^{2} \\
\text { (every } 3 \mathrm{wk} \text { ) }\end{array}$ & $\begin{array}{l}\text { Median OS } 10.3 \text { mos } \\
\text { Median PFS } 4.6 \text { mos }\end{array}$ \\
\hline Borghaei et al $\left.\right|^{82}$ & ॥ & 53 & $\begin{array}{l}\text { Cb AUC } 6 \\
\text { T I00 mg/m² }(\mathrm{dl}, 8,15) \\
\text { (every } 4 \mathrm{wk} \text { ) }\end{array}$ & $\begin{array}{l}\text { Median OS } 13.8 \mathrm{mos} \\
\text { Median TTP } 5.5 \mathrm{mos}\end{array}$ \\
\hline Bradford et $a^{85}$ & ॥ & 57 & $\mathrm{Cb} A \cup C 6$ & Pending \\
\hline $\begin{array}{l}\text { Lilenbaum et al }{ }^{86} \\
\text { (PS } 2 \text { patients) }\end{array}$ & ॥ & 55 & $\begin{array}{l}\text { Doc }\left(30 \mathrm{mg} / \mathrm{m}^{2} \text { wkly for } 3 \mathrm{wk}\right) \text { or } \\
\text { Bortezomib }\left(1.6 \mathrm{mg} / \mathrm{m}^{2} \text { wkly for } 3 \mathrm{wk}\right) \\
\text { (every } 4 \mathrm{wk})\end{array}$ & $\begin{array}{l}\text { Median OS } 3.8 \text { vs } 3.3 \mathrm{mos} \\
\text { Median PFS } 3.1 \text { vs } 1.8 \mathrm{mos}\end{array}$ \\
\hline Rosell et al $\left.\right|^{87}$ & ॥ & 86 & $\begin{array}{l}\text { CDDP } 80 \mathrm{mg} / \mathrm{m}^{2} \\
\text { Vinorlebine } 25 \mathrm{mg} / \mathrm{m}^{2}(\mathrm{dl}, 8) \\
\text { (every } 3 \mathrm{wk} \text { ) }\end{array}$ & $\begin{array}{l}\text { Median OS } 8.3 \text { mos } \\
\text { Median PFS } 5 \text { mos }\end{array}$ \\
\hline Pirker et al ${ }^{71,88}$ & III & 1125 & $\begin{array}{l}\text { CDDP } 80 \mathrm{mg} / \mathrm{m}^{2} \\
\text { Vinorlebine } 25 \mathrm{mg} / \mathrm{m}^{2}(\mathrm{dl}, 8) \\
\text { (every } 3 \mathrm{wk} \text { ) }\end{array}$ & $\begin{array}{l}\text { Median OS } 11.3 \text { mos } \\
\text { Median PFS NR }\end{array}$ \\
\hline Lynch et $\mathrm{al}^{89}$ & III & 676 & $\begin{array}{l}\text { Cb AUC } 6 \text { with } \\
\mathrm{T}\left(225 \mathrm{mg} / \mathrm{m}^{2}\right) \\
\text { or } \\
\text { Dose }\left(75 \mathrm{mg} \mathrm{mg} / \mathrm{m}^{2}\right) \\
\text { (every } 3 \mathrm{wk} \text { ) }\end{array}$ & $\begin{array}{l}\text { Median OS NR } \\
\text { Median PFS } 4.4 \text { mos }\end{array}$ \\
\hline
\end{tabular}

${ }^{\text {aAll }}$ evaluated chemotherapy in addition to cetuximab $\left(400 \mathrm{mg} / \mathrm{m}^{2}\right.$ iv during the first week followed by $250 \mathrm{mg} / \mathrm{m}^{2}$ iv weekly) unless otherwise specified. Abbreviations: Cb, carboplatin; T, paclitaxel; CDDP, cisplatin; Gem, gemcitabine; AUC, area under the curve; Doc, docetaxel; OS, overall survival; PFS, progression-free survival; mos, months; wk, weeks; NR, not reported;TTP, time to progression. 
were $40 \%$ and $16 \%$, respectively. Pharmacokinetic sampling did not reveal an interaction between carboplatin, paclitaxel, and cetuximab.

In another similar phase I/II study, Robert et al evaluated the use of cetuximab in combination with carboplatin and gemcitabine in previously untreated, advanced NSCLC patients. ${ }^{78}$ All tumors were positive for EGFR receptor by IHC $(>1+)$. Thirty-five patients received treatment with cetuximab with standard dosing. Carboplatin (AUC 5, day 1) and gemcitabine $1000 \mathrm{mg} / \mathrm{m}^{2}$ on days 1 and 8 were administered every 3 weeks. Responses included 10 partial responses (PR) (28.6\%). Twenty-one patients had stable disease (SD). The median TTP was 165 days, and the median overall survival (OS) was 310 days. Butts et al randomized 65 patients with advanced metastatic NSCLC in a phase II study to receive gemcitabine ( 1250 or $1000 \mathrm{mg} / \mathrm{m}^{2} \mathrm{iv}$, days 1 and 8 ) plus cisplatin $\left(75 \mathrm{mg} / \mathrm{m}^{2}\right.$ every 3 weeks) or carboplatin (AUC 5 every 3 weeks), with or without cetuximab in standard dosing. ${ }^{79}$ Median PFS and OS were marginally better in patients that received cetuximab (PFS: 5.09 vs 4.21 months, OS: 11.99 vs 9.26 months). Spigel et al evaluated the combination of gemcitabine $1000 \mathrm{mg} / \mathrm{m}^{2}$ iv and docetaxel $30 \mathrm{mg} / \mathrm{m}^{2}$ iv days 1,8 in combination with standard dosing of cetuximab in newly diagnosed unresectable stage III/IV NSCLC. ${ }^{80}$ Twenty-seven patients were included in this analysis $(n=66$ planned). Accrual was temporarily suspended due to a higher than anticipated rate of cetuximab-based hypersensitivity reactions. Overall response rate (ORR) was $13 \%, 9$ patients $(39 \%)$ had SD and 7 patients had progressive disease

Several phase II studies examined the role of maintenance cetuximab in addition to its use with upfront chemotherapy. Belani et al enrolled 80 previously untreated patients in a phase II study to receive standard doses of cetuximab plus docetaxel (at a dose of $75 \mathrm{mg} / \mathrm{m}^{2}$ on day 1) and carboplatin (AUC 6 on day 1) every 21 days for up to 6 cycles. ${ }^{81}$ Thereafter, patients without evidence of disease progression were continued on single-agent cetuximab for a maximum of 1 year or until disease progression. The objective response rate was $15.2 \%$, with a median PFS of 4.6 months and a median OS of 10.3 months. Another similar phase II trial by Borghaei et al evaluated the use of standard doses of cetuximab in combination with monthly carboplatin (AUC 6 day 1) and weekly paclitaxel (100 mg/m² days 1,8 , and 15) every 4 weeks. ${ }^{82}$ In patients without disease progression or limiting toxicity, cetuximab was continued as a single agent after 6 full cycles of therapy (28\% of the patients). Fifty-three patients were accrued. ORR was $57 \%$ and $23 \%$ had SD. Median TTP was 5.5 months, median survival was 13.8 months; 1-year OS 53\%, 2-year OS 18\%. Saleh et al evaluated two different schedules of chemotherapy administration in addition to standard doses of cetuximab. ${ }^{83}$ Beginning on day 8 , a schedule of iv carboplatin (AUC 6) and paclitaxel $225 \mathrm{mg} / \mathrm{m}^{2}$ given on a 3-week cycle was compared with a schedule of iv carboplatin (AUC 6) every 4 weeks and paclitaxel $100 \mathrm{mg} / \mathrm{m}^{2}$ weekly for 3 weeks of each 4-week cycle. Patients who achieved CR, PR, or SD after 4 cycles continued on weekly cetuximab monotherapy until disease progression or unacceptable toxicity. Cetuximab combined with chemotherapy in both dose schedules demonstrated activity and an acceptable toxicity profile. The Southwestern Oncology Group (SWOG) randomized untreated patients with advanced stage NSCLC to receive paclitaxel $225 \mathrm{mg} / \mathrm{m}^{2}$ and carboplatin (AUC 6) every 3 weeks plus standard doses of cetuximab concurrently followed by maintenance cetuximab or sequential chemotherapy for 4 cycles followed by cetuximab. ${ }^{84}$ Treatment was continued until disease progression. Toxicities were significantly increased with concurrent therapy. A phase II trial of paclitaxel, carboplatin, cetuximab, and bevacizumab in this patient population is ongoing (SWOG 0536) in anticipation of a phase III trial. Carboplatin (AUC 6) every 3 weeks for 4 cycles (12 weeks) was used in combination with cetuximab in a phase II trial. ${ }^{85}$ Final PFS and OS data are pending (Table 1).

Table 2 Trials evaluating the use of cetuximab with chemotherapy in relapsed/refractory in Stage IIIb/IV NSCLC

\begin{tabular}{|c|c|c|c|c|}
\hline Author & Phase & $\mathbf{n}$ & Treatment & Results \\
\hline Hanna et $\mathrm{a}^{90}$ & II & 66 & Weekly cetuximab & $\begin{array}{l}\text { ORR } 4.5 \% \\
\text { Median OS } 8.9 \mathrm{mos} \\
\text { Median TTP } 2.3 \mathrm{mos}\end{array}$ \\
\hline Jalal et al ${ }^{91}$ & $\mathrm{I} / \mathrm{lla}$ & 23 & $\begin{array}{l}\text { Weekly cetuximab }+ \\
\text { Pem }\left(750 \mathrm{mg} / \mathrm{m}^{2} \text { iv every } 3 \text { weeks }\right)\end{array}$ & $\begin{array}{l}\text { ORR } 9.5 \% \\
\text { Median TTP } 5.5 \text { mos }\end{array}$ \\
\hline Kim et $\mathrm{a}^{92}$ & II & 47 & $\begin{array}{l}\text { Weekly cetuximab }+ \\
\left.\text { Doc ( } 75 \mathrm{mg} / \mathrm{m}^{2} \text { iv every } 3 \text { weeks }\right)\end{array}$ & Median TTP 89 days \\
\hline
\end{tabular}

Abbreviations: OS, overall survival; TTP, time to progression; Pem, pemetrexed; ORR, overall response rate. 
Lilenbaum et al randomized untreated patients with advanced NSCLC and PS 2 to docetaxel $\left(30 \mathrm{mg} / \mathrm{m}^{2}\right.$ weekly for 3 weeks in a 28-day cycle) in combination with either cetuximab or bortezomib $\left(1.6 \mathrm{mg} / \mathrm{m}^{2}\right.$ weekly for 3 weeks in a 28-day cycle) for 4 cycles. ${ }^{86}$ Patients whose disease was controlled (CR/PR/SD) were allowed to continue cetuximab or bortezomib until progressive disease. Sixty-four patients were enrolled; median PFS was 3.1 months for cetuximab and 1.8 months for bortezomib. Median survival was 3.8 months for cetuximab and 3.3 months for bortezomib.

In a randomized phase II study, Rosell et al randomized 86 chemo-naive patients with advanced $\operatorname{EGFR}(>1+\mathrm{IHC})$ expressing NSCLC to every 3 weeks cisplatin $\left(80 \mathrm{mg} / \mathrm{m}^{2}\right.$, day 1) with vinorelbine $\left(25 \mathrm{mg} / \mathrm{m}^{2}\right.$ on days 1 and 8$)$ with or without weekly cetuximab ${ }^{87}$ Median PFS was higher for the cetuximab group ( $5.0 \mathrm{vs} 4.6$ months, hazard ratio 0.71 ). There was also a trend toward improved OS (8.3 vs 7.3 months, hazard ratio 0.71 ). The cetuximab combination was well tolerated. This combination was further validated in a prospective randomized phase III trial. ${ }^{71,88}$ Tumor samples from 1688 patients were analyzed. A total of 1125 patients with EGFR expressing tumors $(>1+\mathrm{IHC})$ were randomized to the above combination. Primary endpoint was OS, and RR, PFS, disease control, and quality of life were secondary endpoints. Cetuximab was continued as maintenance therapy in the cetuximab arm until disease progression or unacceptable toxicity. The percentage of patients who received single-agent cetuximab and the duration of treatment with this agent were not reported. Addition of cetuximab was associated with a superior OS over chemotherapy alone in all patients with EGFR-detectable advanced NSCLC (median OS 11.3 vs 10.1 months, $P=0.0441$ ). Even though the 121 Asian patients enrolled in the study had prolonged OS compared to Caucasians (median OS 19.5 mos vs 9.6 mos), they did not achieve a survival benefit by addition of cetuximab to chemotherapy compared to chemotherapy alone (17.6 vs 20.4 months, $P=0.49$ ). There was also no significant difference in PFS in the two treatment arms.

In another large phase III trial, Lynch et al randomized previously untreated stage IIIb/IV NSCLC patients to receive either paclitaxel $\left(225 \mathrm{mg} / \mathrm{m}^{2}\right.$ iv) or docetaxel $\left(75 \mathrm{mg} \mathrm{mg} / \mathrm{m}^{2}\right.$ iv) and carboplatin (AUC 6 iv) every 3 weeks with or without cetuximab. ${ }^{89}$ The choice of taxane was at the discretion of the investigator. A total of 676 six patients were randomized at 97 centers in the United States. There were no statistically significant differences in PFS (4.4 vs 4.2 months, $P=0.23$ ). ORR, however, was statistically significantly superior for the cetuximab arm $(25.7 \%$ vs $17.2 \%, P=0.0066)$.

\section{Clinical efficacy in recurrent disease}

Hanna et al evaluated single-agent cetuximab used at its standard dosing schedule in 66 recurrent NSCLC patients (60 EGFR positive by IHC), ORR was $4.5 \%$ and $30.3 \%$ of patients achieved SD. Median TTP and OS were 2.3 months and 8.9 months, respectively. ${ }^{90}$ ORR in the EGFR positive population was $5 \%$. All three patients with CR had EGFR positive tumors. An exploratory analysis of EGFR mutational status was performed on 38 tumor specimens. Three patients had activating mutations (2 patients with SD, 1 PD).

Jalal et al evaluated the feasibility of combining pemetrexed and cetuximab in a phase I/IIa study, in patients with recurrent, previously treated NSCLC with $\geq 1$ prior platinum containing regimen. ${ }^{91}$ Prior use of EGFR TKIs was permitted. Cetuximab was given at a standard dosing schedule. Pemetrexed, however, was administered at $750 \mathrm{mg} / \mathrm{m}^{2}$ iv every 3 weeks. After completing at least 4 cycles, patients with non-progressive disease were allowed to continue cetuximab alone until progression. PR was seen in 2 patient (8.7\%), 8 patients (34.8\%) had SD. Median TTP was 5.5 mos. This combination resulted in longer time to progression when compared with historical controls of pemetrexed alone administered at a dose of $500 \mathrm{mg} / \mathrm{m}^{2}$ every 21 days.

In a phase II trial by Kim et al 47 patients with refractory NSCLC or who had disease recurrence within 3 months after chemotherapy and tumor overexpression of EGFR of at least $1+$ by IHC received cetuximab with docetaxel $\left(75 \mathrm{mg} / \mathrm{m}^{2}\right.$ iv every 3 weeks). ${ }^{92}$ Thirteen patients (28\%) achieved PR and $8(17 \%)$ had SD. Median TTP was 89 days.

\section{Clinical efficacy in combination with radiation therapy}

Cetuximab when added to radiation therapy (RT) statistically significantly improved median survival and loco regional control in treatment of locally advanced squamous cell carcinomas of the head and neck. ${ }^{93}$ Based on these encouraging results, a phase I study was designed to assess the safety of concomitant cetuximab and radical RT in patients with inoperable Stage III NSCLC ${ }^{94}$ Patients received weekly iv cetuximab (in an initial dose of $400 \mathrm{mg} / \mathrm{m}^{2}$; maintenance dose $250 \mathrm{mg} / \mathrm{m}^{2}$ ) after platinum-based induction therapy and concomitant RT (64 Gy/32fractions/45 days). The results suggested that the early and late toxicities of concomitant cetuximab and radical RT were acceptable.

An ongoing radiation therapy oncology group (RTOG) trial, RTOG 0324, is evaluating the combination of cetuximab with RT in unresectable stage III NSCLC patients. ${ }^{95}$ Cetuximab in an initial dose of $400 \mathrm{mg} / \mathrm{m}^{2}$ iv is 
followed by weekly doses of $250 \mathrm{mg} / \mathrm{m}^{2}$ until completion of therapy. RT was started the week after loading dose (63 Gy/35 fractions) with weekly carboplatin (AUC 2) and paclitaxel $\left(45 \mathrm{mg} / \mathrm{m}^{2} \times 6\right.$ doses) to be followed by 2 cycles of carboplatin (AUC 6) and paclitaxel $\left(200 \mathrm{mg} / \mathrm{m}^{2}\right)$. An interim analysis showed improvement in OS compared to historical controls (response rate 62\% $(n=54)$, median survival 22.7 monthss and 2-year OS of $49.3 \%$ ).

The Cancer and Leukemia Group B (CALGB) is evaluating the combination of carboplatin (AUC 5) iv and pemetrexed $\left(500 \mathrm{mg} / \mathrm{m}^{2}\right)$ iv every 3 weeks with concurrent RT (70 Gy over 7 weeks) with or without the use of cetuximab followed by 4 cycles of consolidation with pemetrexed. ${ }^{96}$ Early evaluation of this CALGB 30407 trial suggests that the combination of thoracic radiation with pemetrexed, carboplatin with or without cetuximab is feasible and is well tolerated.

\section{Safety and tolerability}

In phase I and II trials, cetuximab was safe and well tolerated. It has non-overlapping toxicities with most chemotherapy agents, making it an attractive agent to be incorporated into chemotherapy and radiation therapy regimens. In the phase I study dose finding trial, 5 episodes of grade 3 or higher toxicity were seen. Toxicity was not related to dose level or number of cycles administered and most common drug related adverse effects were fevers, chills, asthenia, transaminitis, and skin toxicity. ${ }^{45}$

Acneiform rash is one of the most common toxicities seen with cetuximab use and occurs in approximately $90 \%$ of treated patients at different grades. ${ }^{97}$ There seems to be a higher response rate in patients in whom cetuximab induces a rash than in cetuximab-treated patients who do not experience a rash. Rash therefore could be a surrogate marker for response. ${ }^{98}$ Cetuximab-induced rash is manageable with the use of topical steroids, topical antibiotics, topical emollients, oral antibiotics, and dose modifications. ${ }^{99-104}$

Other toxicities with cetuximab include infusion-related hypersensitivity reactions, which have been associated with the presence of an IgE antibody against glycosylation sites on cetuximab. ${ }^{105,106}$ These reactions were more common in patients with prior allergy history and are less commonly seen with panitumumab, which is a fully human IgG2 antibody. Hypomagnesemia is a class effect of EGFR inhibitors and is commonly seen with use of cetuximab. ${ }^{107,108}$

\section{Conclusions}

The EGFR receptor is often overexpressed in NSCLCs, making cetuximab an attractive drug. Cetuximab is fairly well tolerated overall and has an acceptable safety and manageable tolerability profile.

In the first-line setting, most phase II studies suggest that adding cetuximab to platinum-based therapies is of clinical benefit. A recently reported phase III trial demonstrated a modest OS benefit when cetuximab was added to cisplatin and vinorelbine in the first-line treatment of NSCLC. ${ }^{71}$ In a second phase III trial, addition of cetuximab to carboplatin and a taxane gave only a marginal additional PFS benefit. ${ }^{89}$ Despite this improvement, there are still some unanswered questions, mainly in terms of patient selection. Optimal selection of patients who would benefit from cetuximab is challenging and is key in its further development as a therapeutic agent in lung cancer. The role of predictive markers like EGFR amplification by FISH, $K R A S$ mutation are being explored and larger prospective studies are needed before they can be routinely used in clinical practice.

Combination studies with other targeted agents, especially vascular endothelial growth factor antagonist, are being explored. Ongoing studies are also evaluating the role of cetuximab in combination with radiation with or without chemotherapy ${ }^{109}$ in locally advanced unresectable NSCLC. While final results are pending, interim analyses reveal that cetuximab is feasible and safe to use with radiation in this patient population.

Cetuximab adds to our arsenal of drugs and represents an improvement in survival outcomes in patients with NSCLC. In upcoming years we anticipate more clinical trials combining cetuximab with new targeted treatments which will hopefully improve outcomes while minimizing toxicity.

\section{Disclosures}

Dr Borghaei is on the speakers' bureau for Eli Lilly, Amgen, and Genentech.

\section{References}

1. Jemal A, Siegel R, Ward E, et al; Cancer statistics, CA Cancer J Clin. 2008;58:71-96.

2. Jemal A, Thun MJ, Ries LA, et al; Annual report to the nation on the status of cancer, 1975-2005, featuring trends in lung cancer, tobacco use, and tobacco control. J Natl Cancer Inst. 2008;100:1672-1694.

3. Goldstraw P, Crowley J, Chansky K, et al; The IASLC Lung Cancer Staging Project: proposals for the revision of the TNM stage groupings in the forthcoming (seventh) edition of the TNM Classification of malignant tumours. $J$ Thorac Oncol. 2007;2:706-714.

4. Greene F, Page D, Fleming I. AJCC Cancer Staging Manual. 6th ed. New York: Springer-Verlag; 2002.

5. Arriagada R, Bergman B, Dunant A, et al. Cisplatin-based adjuvant chemotherapy in patients with completely resected non-small-cell lung cancer. $N$ Engl J Med. 2004;350:351-360.

6. Douillard JY, Rosell R, De Lena M, et al. Adjuvant vinorelbine plus cisplatin versus observation in patients with completely resected stage IB-IIIA non-small-cell lung cancer (Adjuvant Navelbine International Trialist Association [ANITA]): a randomised controlled trial. Lancet Oncol. 2006;7:719-727. 
7. Scagliotti GV, Fossati R, Torri V, et al. Randomized study of adjuvant chemotherapy for completely resected stage I, II, or IIIA non-small-cell Lung cancer. J Natl Cancer Inst. 2003;95:1453-1461.

8. Waller D, Peake MD, Stephens RJ, et al. Chemotherapy for patients with non-small cell lung cancer: the surgical setting of the Big Lung Trial. Eur J Cardiothorac Surg. 2004;26:173--182.

9. Winton T, Livingston R, Johnson D, et al. Vinorelbine plus cisplatin vs observation in resected non-small-cell lung cancer. $N$ Engl $J$ Med. 2005;352:2589-2597.

10. Strauss GM, Herndon JE 2nd, Maddaus MA, et al. Adjuvant paclitaxel plus carboplatin compared with observation in stage IB non-small-cell lung cancer: CALGB 9633 with the Cancer and Leukemia Group B, Radiation Therapy Oncology Group, and North Central Cancer Treatment Group Study Groups. J Clin Oncol. 2008;26:5043-5051.

11. West H, Albain KS. Current standards and ongoing controversies in the management of locally advanced non-small cell lung cancer. Semin Oncol. 2005;32:284-292.

12. Eagan RT, Frytak S, Richardson RL, et al. A randomized comparative trial of sequential versus alternating cyclophosphamide, doxorubicin, and cisplatin and mitomycin, lomustine, and methotrexate in metastatic non-small-cell lung cancer. J Clin Oncol. 1988;6:5-8.

13. Cartei G, Cartei F, Cantone A, et al. Cisplatin-cyclophosphamidemitomycin combination chemotherapy with supportive care versus supportive care alone for treatment of metastatic non-small-cell lung cancer. J Natl Cancer Inst. 1993;85:794-800.

14. Mattson K, Maasilta P, Tammilehto L, et al. Trimetrexate and cyclophosphamide for metastatic inoperable nonsmall cell lung cancer. Semin Oncol. 1988;15:32-37.

15. Effects of vinorelbine on quality of life and survival of elderly patients with advanced non-small-cell lung cancer. The Elderly Lung Cancer Vinorelbine Italian Study Group. J Natl Cancer Inst. 1999;91:66-72.

16. Anderson H, Hopwood P, Stephens RJ, et al. Gemcitabine plus best supportive care (BSC) vs BSC in inoperable non-small cell lung cancer - a randomized trial with quality of life as the primary outcome. UK NSCLC Gemcitabine Group. Non-Small Cell Lung Cancer. Br J Cancer. 2000;83:447-453.

17. Ranson MR, White S, Thatcher N. Management of elderly patients with lung cancer. Curr Oncol Rep. 2000;2:90-95.

18. Sandler AB, Nemunaitis J, Denham C, et al. Phase III trial of gemcitabine plus cisplatin versus cisplatin alone in patients with locally advanced or metastatic non-small-cell lung cancer. J Clin Oncol. 2000;18:122-130.

19. Wozniak AJ, Crowley JJ, Balcerzak SP, et al. Randomized trial comparing cisplatin with cisplatin plus vinorelbine in the treatment of advanced non-small-cell lung cancer: a Southwest Oncology Group study. J Clin Oncol. 1998;16:2459-2465.

20. Kelly K, Crowley J, Bunn PA Jr, et al. Randomized phase III trial of paclitaxel plus carboplatin versus vinorelbine plus cisplatin in the treatment of patients with advanced non - small-cell lung cancer: a Southwest Oncology Group trial. J Clin Oncol. 2001;19:3210-3218.

21. Scagliotti GV, De Marinis F, Rinaldi M, et al. Phase III randomized trial comparing three platinum-based doublets in advanced non-small-cell lung cancer. J Clin Oncol. 2002;20:4285-4291.

22. Schiller JH, Harrington D, Belani CP, et al. Comparison of four chemotherapy regimens for advanced non-small-cell lung cancer. $N$ Engl J Med. 2002;346:92-98.

23. Sandler A, Gray R, Perry MC, et al. Paclitaxel-carboplatin alone or with bevacizumab for non-small-cell lung cancer. $N$ Engl $J$ Med. 2006;355:2542-2550.

24. Reck M, von Pawel J, Zatloukal P, et al. Phase III trial of cisplatin plus gemcitabine with either placebo or bevacizumab as first-line therapy for nonsquamous non-small-cell lung cancer: Avail. J Clin Oncol. 2009;27:1227-1234.

25. Scagliotti GV, Parikh P, von Pawel J, et al. Phase III study comparing cisplatin plus gemcitabine with cisplatin plus pemetrexed in chemotherapy-naive patients with advanced-stage non-small-cell lung cancer. J Clin Oncol. 2008;26:3543-3551.
26. Lustberg MB, Edelman MJ. Optimal duration of chemotherapy in advanced non-small cell lung cancer. Curr Treat Options Oncol. 2007:8:38-46.

27. Socinski MA, Stinchcombe TE. Duration of first-line chemotherapy in advanced non small-cell lung cancer: less is more in the era of effective subsequent therapies. J Clin Oncol. 2007;25: $5155-5157$

28. Salomon DS, Brandt R, Ciardiello F, et al. Epidermal growth factor-related peptides and their receptors in human malignancies. Crit Rev Oncol Hematol. 1995;19:183-232.

29. Ford AC, Grandis JR. Targeting epidermal growth factor receptor in head and neck cancer. Head Neck. 2003;25:67-73.

30. Mendelsohn J. Targeting the epidermal growth factor receptor for cancer therapy. J Clin Oncol. 2002;20:1S-13S.

31. Citri A, Yarden Y. EGF-ERBB signalling: towards the systems level. Nat Rev Mol Cell Biol. 2006;7:505-516.

32. Hynes NE, Lane HA. ERBB receptors and cancer: the complexity of targeted inhibitors. Nat Rev Cancer. 2005;5:341-354.

33. Ferraro B, Bepler G, Sharma S, et al. EGR1 predicts PTEN and survival in patients with non-small-cell lung cancer. J Clin Oncol. 2005;23:1921-1926.

34. Haura EB, Zheng Z, Song L, et al. Activated epidermal growth factor receptor-Stat-3 signaling promotes tumor survival in vivo in non-small cell lung cancer. Clin Cancer Res. 2005;11:8288-8294.

35. Lo HW, Hsu SC, Ali-Seyed M, et al. Nuclear interaction of EGFR and STAT3 in the activation of the iNOS/NO pathway. Cancer Cell. 2005;7:575-589.

36. Shepherd FA, Rodrigues Pereira J, Ciuleanu T, et al. Erlotinib in previously treated non-small-cell lung cancer. $N$ Engl $J$ Med. 2005;353:123-132.

37. Tsao MS, Sakurada A, Cutz JC, et al. Erlotinib in lung cancer - molecular and clinical predictors of outcome. $N$ Engl J Med. 2005;353: 133-144.

38. Herbst RS, Prager D, Hermann R, et al. TRIBUTE: a phase III trial of erlotinib hydrochloride (OSI-774) combined with carboplatin and paclitaxel chemotherapy in advanced non-small-cell lung cancer. J Clin Oncol. 2005;23:5892-5899.

39. Gatzemeier U, Pluzanska A, Szczesna A, et al. Phase III study of erlotinib in combination with cisplatin and gemcitabine in advanced non-small-cell lung cancer: The Tarceva Lung Cancer Investigation Trial. J Clin Oncol. 2007;25:1545-1552.

40. Baselga J: New therapeutic agents targeting the epidermal growth factor receptor. J Clin Oncol 2000;18:54S-59S.

41. Goldstein NI, Prewett M, Zuklys K, et al. Biological efficacy of a chimeric antibody to the epidermal growth factor receptor in a human tumor xenograft model. Clin Cancer Res. 1995;1:1311-1318.

42. Baselga J. The EGFR as a target for anticancer therapy - focus on cetuximab. Eur J Cancer. 2001;37 Suppl 4:S16-S22.

43. Baselga J. Targeting the epidermal growth factor receptor: a clinical reality. J Clin Oncol. 2001;19:S41-S44.

44. Baselga J. A review of EGFR targeted therapy. Clin Adv Hematol Oncol. 2003;1:218-219.

45. Baselga J, Pfister D, Cooper MR, et al. Phase I studies of antiepidermal growth factor receptor chimeric antibody $\mathrm{C} 225$ alone and in combination with cisplatin. J Clin Oncol. 2000;18:904-914.

46. Robert F, Ezekiel MP, Spencer SA, et al. Phase I study of anti-epidermal growth factor receptor antibody cetuximab in combination with radiation therapy in patients with advanced head and neck cancer. $J$ Clin Oncol. 2001;19:3234-3243.

47. Li S, Schmitz KR, Jeffrey PD, et al. Structural basis for inhibition of the epidermal growth factor receptor by cetuximab. Cancer Cell. 2005;7:301-311.

48. Marshall J. Clinical implications of the mechanism of epidermal growth factor receptor inhibitors. Cancer. 2006;107:1207-1218.

49. Sigismund S, Argenzio E, Tosoni D, et al. Clathrin-mediated internalization is essential for sustained EGFR signaling but dispensable for degradation. Dev Cell. 2008;15:209-219. 
50. Holbro T, Hynes NE. ErbB receptors: directing key signaling networks throughout life. Annu Rev Pharmacol Toxicol. 2004;44:195-217.

51. Fan Z, Shang BY, Lu Y, et al. Reciprocal changes in p27(Kip1) and $\mathrm{p} 21(\mathrm{Cip} 1)$ in growth inhibition mediated by blockade or overstimulation of epidermal growth factor receptors. Clin Cancer Res. 1997;3:1943-1948.

52. Peng D, Fan Z, Lu Y, et al. Anti-epidermal growth factor receptor monoclonal antibody 225 up-regulates p27KIP1 and induces G1 arrest in prostatic cancer cell line DU145. Cancer Res. 1996;56:3666-3669.

53. Wu X, Rubin M, Fan Z, et al. Involvement of p27KIP1 in G1 arrest mediated by an anti-epidermal growth factor receptor monoclonal antibody. Oncogene. 1996;12:1397-1403.

54. Zandi R, Larsen AB, Andersen $\mathrm{P}$, et al. Mechanisms for oncogenic activation of the epidermal growth factor receptor. Cell Signal. 2007;19:2013-2023.

55. Kurai J, Chikumi H, Hashimoto K, et al. Antibody-dependent cellular cytotoxicity mediated by cetuximab against lung cancer cell lines. Clin Cancer Res. 2007;13:1552-1561.

56. Fan Z, Baselga J, Masui H, et al. Antitumor effect of antiepidermal growth factor receptor monoclonal antibodies pluscisdiamminedichloroplatinum on well established A431 cell xenografts. Cancer Res. 1993;53:4637-4642.

57. Hoffmann T, Hafner D, Ballo H, et al. Antitumor activity of anti-epidermal growth factor receptor monoclonal antibodies and cisplatin in ten human head and neck squamous cell carcinoma lines. Anticancer Res. 1997;17:4419-4425.

58. Baselga J, Norton L, Albanell J, et al. Recombinant humanized anti-HER2 antibody (Herceptin) enhances the antitumor activity of paclitaxel and doxorubicin against HER2/neu overexpressing human breast cancer xenografts. Cancer Res. 1998;58:2825-2831.

59. Inoue K, Slaton JW, Perrotte P, et al. Paclitaxel enhances the effects of the anti-epidermal growth factor receptor monoclonal antibody ImClone $\mathrm{C} 225$ in mice with metastatic human bladder transitional cell carcinoma. Clin Cancer Res. 2000;6:4874-4884.

60. Blagosklonny MV, Schulte T, Nguyen P, et al. Taxol-induced apoptosis and phosphorylation of Bcl-2 protein involves c-Raf-1 and represents a novel c-Raf-1 signal transduction pathway. Cancer Res. 1996;56:1851-1854.

61. Garcia R, Franklin RA, McCubrey JA. EGF induces cell motility and multi-drug resistance gene expression in breast cancer cells. Cell Cycle. 2006;5:2820-2826.

62. Yun $\mathrm{CH}$, Mengwasser KE, Toms AV, et al. The T790M mutation in EGFR kinase causes drug resistance by increasing the affinity for ATP. Proc Natl Acad Sci U S A. 2008;105:2070-2075.

63. Wang SE, Narasanna A, Perez-Torres M, et al. HER2 kinase domain mutation results in constitutive phosphorylation and activation of HER2 and EGFR and resistance to EGFR tyrosine kinase inhibitors. Cancer Cell. 2006;10:25-38.

64. Rothenberg SM, Engelman JA, Le S, et al. Modeling oncogene addiction using RNA interference. Proc Natl Acad Sci U S A. 2008;105:12480-12484.

65. Engelman JA, Zejnullahu K, Mitsudomi T, et al. MET amplification leads to gefitinib resistance in lung cancer by activating ERBB3 signaling. Science. 2007;316:1039-1043.

66. Morgillo F, Kim WY, Kim ES, et al. Implication of the insulin-like growth factor-IR pathway in the resistance of non-small cell lung cancer cells to treatment with gefitinib. Clin Cancer Res. 2007;13: 2795-2803.

67. Amado RG, Wolf M, Peeters M, et al. Wild-type KRAS is required for panitumumab efficacy in patients with metastatic colorectal cancer. J Clin Oncol. 2008;26:1626-1634.

68. Karapetis CS, Khambata-Ford S, Jonker DJ, et al. K-ras mutations and benefit from cetuximab in advanced colorectal cancer. $N$ Engl $J$ Med. 2008;359:1757-1765.

69. Lievre A, Bachet JB, Le Corre D, et al. KRAS mutation status is predictive of response to cetuximab therapy in colorectal cancer. Cancer Res. 2006;66:3992-3995.
70. Pao W, Wang TY, Riely GJ, et al. KRAS mutations and primary resistance of lung adenocarcinomas to gefitinib or erlotinib. PLoS Med. 2005;2:e17.

71. Pirker R, Pereira JR, Szczesna A, et al. Cetuximab plus chemotherapy in patients with advanced non-small-cell lung cancer (FLEX): an openlabel randomised phase III trial. Lancet. 2009;373:1525-1531.

72. O'Byrne K, Bondarenko I, Barrios C. Molecular and clinical predictors of outcome for cetuximab in non-small cell lung cancer (NSCLC): Data from the FLEX study. J Clin Oncol, 2009 ASCO Annual Meeting Proceedings. J Clin Oncol. 2009;27:15s, (suppl; abstr 8007).

73. Cappuzzo F, Ligorio C, Toschi L, et al. EGFR and HER2 gene copy number and response to first-line chemotherapy in patients with advanced non-small cell lung cancer (NSCLC). J Thorac Oncol. 2007;2:423-429.

74. Hirsch FR, Varella-Garcia M, Cappuzzo F, et al. Combination of EGFR gene copy number and protein expression predicts outcome for advanced non-small-cell lung cancer patients treated with gefitinib. Ann Oncol. 2007;18:752-760.

75. Hirsch FR, Herbst RS, Olsen C, et al. Increased EGFR gene copy number detected by fluorescent in situ hybridization predicts outcome in non-small-cell lung cancer patients treated with cetuximab and chemotherapy. J Clin Oncol. 2008;26:3351-3357.

76. Cerny T, Barnes DM, Hasleton P, et al. Expression of epidermal growth factor receptor (EGF-R) in human lung tumours. Br J Cancer. 1986;54:265-269.

77. Thienelt CD, Bunn PA Jr, Hanna N, et al. Multicenter phase I/II study of cetuximab with paclitaxel and carboplatin in untreated patients with stage IV non-small-cell lung cancer. J Clin Oncol. 2005;23:8786-8793.

78. Robert F, Blumenschein G, Herbst RS, et al. Phase I/IIa study of cetuximab with gemcitabine plus carboplatin in patients with chemotherapy-naive advanced non-small-cell lung cancer. J Clin Oncol. 2005;23:9089-9096.

79. Butts CA, Bodkin D, Middleman EL, et al. Randomized phase II study of gemcitabine plus cisplatin or carboplatin [corrected], with or without cetuximab, as first-line therapy for patients with advanced or metastatic non small-cell lung cancer. J Clin Oncol. 2007;25:5777-5784.

80. Spigel D, Greco F, Burris H. Docetaxel, gemcitabine, and cetuximab in untreated advanced non-small cell lung cancer: P3-144. 12th World Conference on Lung Cancer; 2007 September 2-6; J Thorac Oncol, Seoul, Korea: 2007;2(8) Suppl 4:S740-S741.

81. Belani CP, Schreeder MT, Steis RG, et al. Cetuximab in combination with carboplatin and docetaxel for patients with metastatic or advancedstage nonsmall cell lung cancer: a multicenter phase 2 study. Cancer. 2008;113:2512-2517.

82. Borghaei H, Langer CJ, Millenson M, et al. Phase II study of paclitaxel, carboplatin, and cetuximab as first line treatment, for patients with advanced non-small cell lung cancer (NSCLC): results of OPN-017. J Thorac Oncol. 2008;3:1286-1292.

83. Saleh M, Socinski M, Trent D. Randomized phase II trial of two dose schedules of carboplatin/paclitaxel/cetuximab in stage IIIB/IV non-small cell lung cancer (NSCLC). ASCO Annual Meeting Proceedings Part I. J Clin Oncol. 2007;25(18S) June 20 Suppl:Abstract 7586.

84. Herbst R, Chansky K, Kelly K. A phase II randomized selection trial evaluating concurrent chemotherapy plus cetuximab or chemotherapy followed by cetuximab in patients with advanced non-small cell lung cancer (NSCLC): Final report of SWOG 0342. ASCO Annual Meeting Proceedings Part I. J Clin Oncol. 2007;25(18S) June 20 Suppl: Abstract 7545

85. Bradford D, Socinski M, LaRocca R. Phase II trial of carboplatin plus cetuximab for the treatment of stage IIIB/IV non-small cell lung cancer (NSCLC). ASCO Annual Meeting Proceedings Part I. J Clin Oncol. 2007;25(18S) June 20 Suppl:Abstract 18005.

86. Lilenbaum R, Wang $\mathrm{X}, \mathrm{Gu} \mathrm{L}$. Phase II randomized trial of docetaxel plus cetuximab or bortezomib in patients with advanced NSCLC and performance status (PS) 2-CALGB 30402. ASCO Annual Meeting Proceedings Part I. J Clin Oncol. 2007;25(18S) June 20 Suppl:Abstract 7595. 
87. Rosell R, Robinet G, Szczesna A, et al. Randomized phase II study of cetuximab plus cisplatin/vinorelbine compared with cisplatin/ vinorelbine alone as first-line therapy in EGFR-expressing advanced non-small-cell lung cancer. Ann Oncol. 2008;19:362-369.

88. Pirker R, Szczesna A, von Pawel J. FLEX: A randomized, multicenter, phase III study of cetuximab in combination with cisplatin/vinorelbine (CV) versus $\mathrm{CV}$ alone in the first-line treatment of patients with advanced non-small cell lung cancer (NSCLC). J Clin Oncol. 2008; 26:(May 20 Suppl):Abstract 3.

89. Lynch T, Taral P, Luke D. A randomized multicenter phase III study of cetuximab $\left(\right.$ Erbitux $\left.^{\circledR}\right)$ in combination with Taxane/Carboplatin versus Taxane/Carboplatin alone as first-line treatment for patients with advanced/metastatic Non-small cell lung cancer (NSCLC): B3-03. J Thorac Oncol. 2007;2(8) Suppl 4:S340-S341.

90. Hanna N, Lilenbaum R, Ansari R, et al. Phase II trial of cetuximab in patients with previously treated non-small-cell lung cancer. J Clin Oncol. 2006; 24:5253-5258.

91. Jalal S, Waterhouse D, Edelman M. Pemetrexed plus cetuximab in patients (pts) with recurrent non-small cell lung cancer (NSCLC): A phase I-IIa dose-ranging study from the Hoosier Oncology Group. ASCO Annual Meeting Proceedings Part I. J Clin Oncol. 2007;25(18S) June 20 Suppl:Abstract 7698.

92. Kim ES, Mauer AM, William WN Jr, et al. A phase 2 study of cetuximab in combination with docetaxel in chemotherapy-refractory/resistant patients with advanced nonsmall-cell lung cancer. Cancer. 2009.

93. Bonner JA, Harari PM, Giralt J, et al. Radiotherapy plus cetuximab for squamous-cell carcinoma of the head and neck. $N$ Engl J Med. 2006;354:567-578.

94. Hughes S, Liong J, Miah A. Safety study of induction chemotherapy and synchronous radiotherapy (RT) and cetuximab in stage III nonsmall cell lung cancer (NSCLC): SCRATCH (Cohort I). ASCO Annual Meeting Proceedings Part I. J Clin Oncol. 2007;25(18S) June 20 Suppl: Abstract 18032

95. Blumenschein G, Paulus R, Curran W. A phase II study of cetuximab (C225) in combination with chemoradiation (CRT) in patients (PTS) with stage IIIA/B non-small cell lung cancer (NSCLC): A report of the 2 year and median survival (MS) for the RTOG 0324 trial. J Clin Oncol. 2008;26:(May 20 Suppl):Abstract 7516.

96. Govindan R, Bogart J, Wang X. A phase II study of pemetrexed, carboplatin and thoracic radiation with or without cetuximab in patients with locally advanced unresectable non-small cell lung cancer: CALGB 30407-Early evaluation of feasibility and toxicity. J Clin Oncol. 2008; 26:(May 20 Suppl):Abstract 7518.
97. Saif MW, Kim R. Incidence and management of cutaneous toxicities associated with cetuximab. Expert Opin Drug Saf. 2007;6:175-182.

98. Perez-Soler R, Saltz L. Cutaneous adverse effects with HER1/ EGFR-targeted agents: is there a silver lining? J Clin Oncol. 2005;23: 5235-5246.

99. Alexandrescu DT, Vaillant JG, Dasanu CA. Effect of treatment with a colloidal oatmeal lotion on the acneform eruption induced by epidermal growth factor receptor and multiple tyrosine-kinase inhibitors. Clin Exp Dermatol. 2007;32:71-74.

100. Chou LS, Garey J, Oishi K, et al. Managing dermatologic toxicities of epidermal growth factor receptor inhibitors. Clin Lung Cancer. 2006;8 Suppl 1:S15-S22.

101. Deslandres M, Sibaud V, Chevreau C, et al. Cutaneous side effects associated with epidermal growth factor receptor and tyrosine kinase inhibitors. Ann Dermatol Venereol Spec. 2008;1:16-24.

102. Rhee J, Oishi K, Garey J, et al. Management of rash and other toxicities in patients treated with epidermal growth factor receptor-targeted agents. Clin Colorectal Cancer. 2005;5 Suppl 2:S101-S106.

103. Scope A, Agero AL, Dusza SW, et al. Randomized double-blind trial of prophylactic oral minocycline and topical tazarotene for cetuximabassociated acne-like eruption. J Clin Oncol. 2007;25:5390-5396.

104. Thomas M: Cetuximab: adverse event profile and recommendations for toxicity management. Clin J Oncol Nurs. 2005;9:332-338.

105. Chung $\mathrm{CH}$, Mirakhur B, Chan E, et al. Cetuximab-induced anaphylaxis and IgE specific for galactose-alpha-1,3-galactose. N Engl J Med. 2008; 358:1109-11017.

106. O’Neil BH, Allen R, Spigel DR, et al. High incidence of cetuximabrelated infusion reactions in Tennessee and North Carolina and the association with atopic history. J Clin Oncol. 2007;25:3644-3648.

107. Groenestege WM, Thebault S, van der Wijst J, et al. Impaired basolateral sorting of pro-EGF causes isolated recessive renal hypomagnesemia. J Clin Invest. 2007;117:2260-2267.

108. Wagner CA. Disorders of renal magnesium handling explain renal magnesium transport. J Nephrol. 2007;20:507-510.

109. NCI: Cetuximab in Lung Cancer | Open Studies. http://clinicaltrials. gov/. Accessed March 01, 2009.
OncoTargets and Therapy

\section{Publish your work in this journal}

OncoTargets and Therapy is an international, peer-reviewed, open access journal focusing on the pathological basis of all cancers, potential targets for therapy and treatment protocols employed to improve the management of cancer patients. The journal also focuses on the impact of management programs and new therapeutic agents and protocols on

\section{Dovepress}

patient perspectives such as quality of life, adherence and satisfaction The manuscript management system is completely online and includes a very quick and fair peer-review system, which is all easy to use. Visit http://www.dovepress.com/testimonials.php to read real quotes from published authors. 